\title{
Growth Hormone and Metasomatotrophic Diabetes: Effects on Insulin and Proinsulin of Serum and Pancreas in Dogs
}

\author{
J. Pierluissi* and J. Campbell \\ Department of Physiology, University of Toronto, Toronto, Ontario, Canada
}

Summary. In normal fasting dog serum, the insulin: proinsulin molar proportion was $71: 29 \%$. In response to glucose infusion, the proinsulin proportion decreased. In the pancreas, the proinsulin proportion was lower than in serum. Growth hormone treatment for one day increased serum insulin sevenfold and proinsulin 18-fold. The proinsulin proportion increased to $49 \%$. The growth hormone injections magnified the response to glucose infusion. The rise in serum insulin was 16 times the normal, proinsulin also rose but its proportion decreased. Growth hormone treatment for 6 days decreased pancreatic insulin to $5 \%$ and proinsulin to $46 \%$ of normal. In the permanent (metasomatotrophic) diabetes produced by the prolonged administration of growth hormone, serum insulin decreased and the proinsulin proportion increased. No rises in serum insulin nor proinsulin occurred following glucose infusion. In the pancreas, insulin and proinsulin were reduced to $1.6 \%$ and $8 \%$ of normal. The reduction in the immunoreactive insulin of the pancreas was more pronounced in the tail than in the head and body regions. The results indicate that in the state of augmented insulin secretion and hyperinsulinaemia produced by growth hormone and in the reduced insulin secretion and hypoinsulinaemia of metasomatotrophic diabetes, the proportion of proinsulin in serum is increased due to beta cell secretion containing a higher proportion of proinsulin than normal.

Key words: Growth hormone effects, somatotrophic diabetes, metasomatotrophic diabetes, hyperinsulinaemia, hyperproinsulinaemia, hypoinsulinaemia, pancreatic insulin and proinsulin

\footnotetext{
* Present address: Department of Physiology, The Jose M. Vargas School of Medicine, Central University of Venezuela, Caracas, Venezuela. Please address requests for offprints to Dr. Campbell
}

In the blood of healthy subjects, proinsulin forms a substantial part of the immunoreactive insulin (IRI) [1]. In the pancreas, however, the proportion of proinsulin is lower $[1,2]$. The roles of the secretion and clearance rates of insulin and proinsulin in the production of this difference between serum and pancreas have been investigated [3]. The proportion of proinsulin in blood is high in some states or cases in which insulin secretion is increased, as in obesity [4], in patients with insulinoma [5-8] and in tolbutamidetreated rats [9]. In certain types of diabetes mellitus, the proinsulin proportion is also elevated $[1,10-14]$.

Growth hormone has the capability of increasing insulin secretion in man [15, 16] and animals [17-19]. However, in the permanent (metasomatotrophic) diabetes produced by the prolonged administration of growth hormone, insulin secretion is low [20]. In extension of our investigations [20,21] we now describe the effects of growth hormone and of metasomatotrophic diabetes in dogs on the insulin and proinsulin of serum and pancreas, under the conditions of fasting and glucose infusion.

\section{Materials and Methods}

Normal adult male dogs were given daily $425 \mathrm{~g}$ canned mcat (Romar Pet Foods, Toronto) and $200 \mathrm{~g}$ dog chow (Purina, Toronto) divided in two meals. The response to glucose was tested about $17 \mathrm{~h}$ after a meal by IV injection of glucose $(1.0 \mathrm{~g} / \mathrm{kg}$ body weight as a $50 \%$ solution of glucose in $0.154 \mathrm{~mol} / 1 \mathrm{NaCl}$ ). In a group of six dogs (initial body weight $15-20 \mathrm{~kg}$, mean serum IRI $23 \mathrm{mU} / 1$ and glucose $4.6 \mathrm{mmol} / \mathrm{l}$ ), bovine growth hormone (Connaught Medical Research Laboratories, Toronto, Lot 100-1, dissolved in $0.154 \mathrm{~mol} / 1 \mathrm{NaCl}, 10 \mathrm{mg} / \mathrm{ml}$, at $\mathrm{pH}$ 8-9) was injected SC twice dai1y. The dose per day was $2.0 \mathrm{mg} / \mathrm{kg}$ body weight for 2 days and $1.0 \mathrm{mg} / \mathrm{kg}$ for the remaining 4 days. At I day after the first of these injections, serum IRI increased 20 -fold: after 2 days serum glucose also rose and all the dogs excreted sugar. The hyperinsulinaemia, hyperglycaemia and glycosuria continued to the time of sacrifice, at 6 days, when the mean serum IRI was $418 \mathrm{mU} / \mathrm{l}$, glucose was $20.2 \mathrm{mmol} / \mathrm{I}$ and sugar excretion was about $25 \mathrm{~g} /$ day [21]. 
In another group of five dogs (initial body weight $13-18 \mathrm{~kg}$, mean serum IRI $24 \mathrm{mU} / 1$ and glucose $4.7 \mathrm{mmol} / 1$ ) growth hormone injected for $33-44$ days $(2.0 \mathrm{mg} / \mathrm{kg}$ for $10-13$ days and $2.6-3.3 \mathrm{mg} / \mathrm{kg}$ thereafter) produced permanent diabetes. After cessation of these injections, serum IRI became subnormal after $2-4$ months, serum glucose remained high (17.7-21.1 mmol/l) and sugar excretion was about $100 \mathrm{~g} /$ day during about 14 months of observation [20].

After 6 days of growth hormone injection and about 14 months of metasomatotrophic diabetes, the dogs were anaesthetized (sodium pentobarbital, $25-30 \mathrm{mg} / \mathrm{kg}$, IV) blood was rapidly withdrawn through a carotid cannula and the excised pancreas was divided into the head (uncinate), body (duodenal) and tail (splenic) regions. The tissue was frozen and later extracted and partially purified according to [22], as described previously [23]. The alcohol-ethyl ether percipitate was dissolved in $0.5 \mathrm{ml}$ of $0.01 \mathrm{~mol} / 1 \mathrm{HCl}$ in $0.154 \mathrm{~mol} / 1$ $\mathrm{NaCl}$. Freeze-dried aliquots of serum $(5.0 \mathrm{ml}$ from metasomatotrophic diabetic and fasting normal dogs and $2.0 \mathrm{ml}$ from growth hormone treated and normal dogs post-glucose) were dissolved in $1.0 \mathrm{ml}$ of distilled water, then extracted as above.

Methods for the partition of extracts by gel filtration and the identification and assay of the insulin and proinsulin-like material (PLM) fractions have been described [3-6, 10, 12]. The fractionation column $(1.0 \times 60 \mathrm{~cm})$ contained Sephadex G 50 superfine (Pharmacia, Uppsala) suspended in $1.0 \mathrm{~mol} / 1$ acetic acid. which was also the fluid for elution and washing. To minimize absorption, $1.0 \mathrm{ml}$ of normal dog serum was passed through the column. Bovine insulin (Connaught Medical Research Laboratories, Fraction $\mathrm{C}$, free of proinsulin) and porcine proinsulin (Lilly Laboratories, Indianapolis, Lot No. 615-1082B-2) were labelled with 125-iodine (Amersham-Searle, Arlington Heights, Illinois, Reagent IMS-30) [24]. The column was calibrated by the application of these labelled and the unlabelled hormones, in several combinations. Two major peaks of radioactivity coincided with the peaks of immunoreactivity, at samples 35 (proinsulin) and 45 (insulin), with satisfactory separation and recovery of about $85 \%$ of the amount applied. In analysis, trace amounts of ${ }^{125} \mathrm{I}$-insulin ( $16 \mathrm{pg}$ ) and of ${ }^{125} \mathrm{I}$-proinsulin (44 $\mathrm{pg}$ ) that were far below the level of detection by radioimmunoassay, were added to the extracts of serum and pancreas, prior to gel filtration. The peaks of radioactivity and of immunoreactivity corresponded. Eluate samples $(0.57 \mathrm{ml})$ under the peaks were pooled, freeze-dried and, for assay, were dissolved in phosphate buffer $(0.05 \mathrm{~mol} / 1, \mathrm{pH} 7.4)$ containing bovine serum albumin, $5.0 \mathrm{~g} / 1$.

Chromatographic fractions of dog pancreas extract, containing labelled insulin and proinsulin, were examined by electrophoresis in $7 \%$ polyacrylamide gel $(\mathrm{pH} 8.9)$ at $3 \mathrm{~mA} /$ tube [25]. The gel column of the PLM fraction had a zone of the same mobility as porcine proinsulin and several zones of greater and lesser mobility. The insulin fraction gel had a zone corresponding to porcine insulin, but no proinsulin zone.

IRI was assayed by a double-antibody method [26], using as reference standard porcine insulin (Lilly Laboratories, $26.2 \mathrm{U} / \mathrm{mg}$ ). The serum IRI values obtained with this standard were found in further studies to be in agreement with those given by assays against canine insulin (Novo Laboratories, Copenhagen). The antibodybinding of porcine proinsulin (Lilly Laboratories, Lot 615-7082B$46-2$ ) was found to be about $40 \%$ of that of porcine insulin, in fair agreement with others $[13,27]$. Porcine C-peptide (Lilly Laboratories, Lot $615-1070 \mathrm{~B}-72$ ) in concentrations of $0.25-20.0 \mathrm{ng} / \mathrm{ml}$, did not react in the assay system, indicating that insulin was the reactive portion of the molecule. The chromatographic PLM fraction was assayed against porcine proinsulin. The antibody-binding of the PLM fraction over a wide range of dilutions was proportional to that of the proinsulin standard, in the concentrations of $0.25-20.0 \mathrm{ng} / \mathrm{ml}$. The molecular weight of canine proinsulin $(8855)$ was obtained as the sum of its C-peptide (mol. wt. 3077, from the amino acid composition) [28] and insulin (mol. wt. 5778). With the assumption that canine and porcine proinsulins reacted equally in the assay system, $1 \mu \mathrm{g}$ of canine proinsulin corresponded to 113 pmol. Serum glucose was determined by means of glucose oxidase and a polarographic electrode [29]. Values are the means \pm SEM: the probability of no real difference between means is given for values $<0.05$.

\section{Results}

\section{Normal Dogs}

In a group of six normal dogs, fasting serum insulin was $141 \mathrm{pmol} / 1$ (equivalent to $21 \mathrm{mU} / 1$ ) and proinsulin was $52 \mathrm{pmol} / 1$ (equivalent to $0.46 \mu \mathrm{g} / \mathrm{l}$ ). The molar proportion of proinsulin was $29 \%$. In these normal dogs, post-glucose (at $15 \mathrm{~min}$ after IV injection $1 \mathrm{~g}$ glucose $/ \mathrm{kg}$ body weight) serum insulin rose significantly by $+508 \mathrm{pmol} / 1$ over the fasting level, while mean serum proinsulin did not increase significantly (increase in three, no change in one and decrease in two dogs). The molar proportion of proinsulin was 9\% (Table 1).

\section{Effects of Growth Hormone}

After 1 day of growth hormone injection, fasting serum insulin and proinsulin increased significantly to about seven and 18 times the normal, respectively. The proinsulin proportion increased significantly to $49 \%$, due to the greater rise in proinsulin than in insulin (Table 1). In response to IV glucose, serum insulin rose significantly by $+8150 \mathrm{pmol} / 1$, over the already high fasting value: this increment was 16 times the normal response. Serum proinsulin also rose after IV glucose by $+540 \mathrm{pmol} / 1$. The greater post-glucose rise in insulin than in proinsulin significantly increased the proportion of insulin to $84 \%$ (Table 1 ).

\section{Metasomatotrophic Diabetes}

In metasomatotrophic diabetes, 30 days after the cessation of the growth hormone injections, serum insulin was significantly below normal. The serum proinsulin level was in the normal range, but the proportion was significantly increased (Table 2). Following IV glucose, no rises in serum insulin nor proinsulin occured and the proportion of proinsulin remained high (Table 2).

\section{Pancreas}

In normal dogs, the tail region of the pancreas had the highest concentration and amount of IRI. The body and head regions followed in order (Table 3). The insulin and proinsulin concentrations in the whole pancreas extract were 16 and $0.24 \mathrm{nmol} / \mathrm{g}$ of tissue, giving the proinsulin proportion of $2 \%$ (Table 4). Growth hormone treatment for 6 days reduced the IRI concentrations in the head, body and tail regions of the pancreas to about 11,10 and $8 \%$ of normal, respec- 
Table 1. Serum insulin and proinsulin in normal and growth hormone-treated dogs, under fasting and post-glucose (at 15 min after IV glucose) conditions

\begin{tabular}{|c|c|c|c|c|c|}
\hline Dogs & $\begin{array}{l}\text { No. of } \\
\text { dogs }\end{array}$ & Conditions & $\begin{array}{l}\text { Insulin } \\
(\mathrm{pmol} / \mathrm{l})\end{array}$ & $\begin{array}{l}\text { Proinsulin } \\
(\mathrm{pmol} / \mathrm{l})\end{array}$ & $\begin{array}{l}\text { Proinsulin } \\
(\mathrm{mol} \%)\end{array}$ \\
\hline $\begin{array}{l}\text { Normal } \\
\text { Normal }\end{array}$ & $\begin{array}{l}6 \\
6\end{array}$ & $\begin{array}{l}\text { Fasting } \\
\text { Post-glucose }\end{array}$ & $\begin{array}{r}141 \pm 27 \\
649 \pm 169\end{array}$ & $\begin{array}{l}52 \pm 9 \\
54 \pm 10\end{array}$ & $\begin{array}{r}29 \pm 5 \\
9 \pm 2\end{array}$ \\
\hline $\begin{array}{l}\text { Growth hormone (1 day) } \\
\text { Growth hormone ( } 1 \text { day) }\end{array}$ & $\begin{array}{l}6 \\
6\end{array}$ & $\begin{array}{l}\text { Fasting } \\
\text { Post-glucose }\end{array}$ & $\begin{array}{r}924 \pm 225 \\
9070 \pm 1620\end{array}$ & $\begin{array}{r}956 \pm 313 \\
1500 \pm 336\end{array}$ & $\begin{array}{l}49 \pm 4 \\
16 \pm 4\end{array}$ \\
\hline \multicolumn{6}{|l|}{ Comparisons } \\
\hline \multicolumn{2}{|c|}{$\begin{array}{l}\text { Normal, fasting vs normal, post-glucose } \\
\text { Normal, fasting vs } \mathrm{GH} \text {, fasting } \\
\text { Normal, fasting vs } \mathrm{GH} \text {, post-glucose } \\
\mathrm{GH} \text {, fasting vs } \mathrm{GH} \text {, post-glucose } \\
\text { Normal, post-glucose vs } \mathrm{GH} \text {, post-glucose }\end{array}$} & & $\begin{array}{l}p<0.025 \\
p<0.010 \\
p<0.005 \\
p<0.005 \\
p<0.001\end{array}$ & $\begin{array}{l}p<0.025 \\
p<0.010 \\
p<0.010\end{array}$ & $\begin{array}{l}p<0.010 \\
p<0.025 \\
p<0.001\end{array}$ \\
\hline
\end{tabular}

Values are expressed as mean \pm SEM.

$\mathrm{GH}=$ growth hormone injected

Table 2. Serum insulin and proinsulin in metasomatotrophic diabetic dogs under fasting and post-glucose (at 15 min after IV glucose) conditions

\begin{tabular}{|c|c|c|c|c|c|}
\hline Dogs & $\begin{array}{l}\text { No. of } \\
\text { dogs }\end{array}$ & Conditions & $\begin{array}{l}\text { Insulin } \\
(\mathrm{pmol} / 1)\end{array}$ & $\begin{array}{l}\text { Proinsulin } \\
\text { (pmol/l) }\end{array}$ & $\begin{array}{l}\text { Proinsulin } \\
(\mathrm{mol} \%)\end{array}$ \\
\hline $\begin{array}{l}\text { Metasomatotrophic } \\
\text { diabetic ( } 30 \text { days) }\end{array}$ & 5 & Fasting & $71 \pm 8$ & $80 \pm 11$ & $53 \pm 5$ \\
\hline $\begin{array}{l}\text { Metasomatotrophic } \\
\text { diabetic ( } 30 \text { days) }\end{array}$ & 5 & $\begin{array}{l}\text { Post- } \\
\text { glucose }\end{array}$ & $50 \pm 4$ & $50 \pm 8$ & $49 \pm 5$ \\
\hline \multicolumn{6}{|l|}{ Comparisons } \\
\hline \multirow{5}{*}{\multicolumn{3}{|c|}{$\begin{array}{l}\text { MSD, fasting vs normal, fasting } \\
\text { MSD, fasting vs GH, fasting } \\
\text { MSD, post-glucose vs normal, fasting } \\
\text { MSD, post-glucose vs normal, post-glucose } \\
\text { MSD, post-glucose vs } G H \text {, post-glucose }\end{array}$}} & $p<0.050$ & \multirow{4}{*}{$p<0.025$} & \multirow[t]{2}{*}{$p<0.025$} \\
\hline & & & $p<0.005$ & & \\
\hline & & & $p<0.010$ & & $p<0.025$ \\
\hline & & & $p<0.010$ & & $p<0.001$ \\
\hline & & & $p<0.001$ & $p<0.005$ & $p<0.001$ \\
\hline
\end{tabular}

Values are expressed as mean \pm SEM

$\mathrm{GH}=$ growth hormone injected; $\mathrm{MSD}=$ metasomatotrophic diabetic

Table 3. Distribution of immunoreactive insulin (IRI) in the pancreas

\begin{tabular}{|c|c|c|c|c|c|c|c|c|c|}
\hline \multirow[t]{3}{*}{ Dogs } & \multirow{3}{*}{$\begin{array}{l}\text { No. } \\
\text { of } \\
\text { dogs }\end{array}$} & \multirow{3}{*}{$\begin{array}{l}\text { Body weight } \\
(\mathrm{kg})\end{array}$} & \multirow{3}{*}{$\begin{array}{l}\text { Pancreas } \\
\text { weight } \\
\text { (g/kg body } \\
\text { weight) }\end{array}$} & \multicolumn{6}{|c|}{ IRI in regions of the pancreas } \\
\hline & & & & \multicolumn{2}{|l|}{ Head } & \multicolumn{2}{|l|}{ Body } & \multicolumn{2}{|l|}{ Tail } \\
\hline & & & & $\begin{array}{l}\text { (U/g of } \\
\text { tissue) }\end{array}$ & $(\%)^{a}$ & $\begin{array}{l}\text { (U/g of } \\
\text { tissue) }\end{array}$ & $(\%)$ & $\begin{array}{l}\text { (U/g of } \\
\text { tissue) }\end{array}$ & $(\%)$ \\
\hline \multirow{3}{*}{$\begin{array}{l}\text { Normal } \\
\text { Growth hormone } \\
\text { ( } 6 \text { days) } \\
\text { Metasoma- } \\
\text { totrophic diabetic } \\
\text { (14 months) }\end{array}$} & \multirow{2}{*}{$\begin{array}{l}3 \\
6\end{array}$} & $15.2 \pm 2.2$ & $2.2 \pm 0.1$ & $2.3 \pm 0.74$ & $13 \pm 2.5$ & $2.6 \pm 0.94$ & $34 \pm 3.4$ & $4.8 \pm 1.9$ & $52 \pm 3.7$ \\
\hline & & $18.2 \pm 0.9$ & $1.6 \pm 0.2$ & $0.26 \pm 0.07$ & $22 \pm 3.3$ & $0.26 \pm 0.07$ & $42 \pm 3.6$ & $0.37 \pm 0.17$ & $36 \pm 4.3$ \\
\hline & 5 & $13.2 \pm 0.9$ & $1.9 \pm 0.3$ & \multicolumn{2}{|c|}{$0.044 \pm 0.00523 \pm 1.1$} & \multicolumn{2}{|c|}{$0.056 \pm 0.01343 \pm 5.3$} & \multicolumn{2}{|c|}{$0.044 \pm 0.00834 \pm 4.5$} \\
\hline \multicolumn{4}{|c|}{ Growth hormone vs metasomatotrophic diabetic } & \multicolumn{2}{|l|}{$p<0.025$} & \multicolumn{2}{|l|}{$p<0.05$} & & \\
\hline
\end{tabular}

Values are expressed as mean \pm SEM

a IRI of the region as precentage of the total pancreatic IRI

tively (Table 3). The insulin and proinsulin concentrations in the whole pancreas extract were reduced to about 5 and $46 \%$ of normal, respectively. The greater reduction in insulin than proinsulin increased the proinsulin proportion to $11 \%$ (Table 4).
In metasomatotrophic diabetes of 14 months duration in five dogs, the IRI of the head, body and tail regions of the pancreas was reduced to about 1.9, 2.1 and $0.92 \%$ of normal respectively (Table 3 ). The insulin and proinsulin concentrations in the whole pan- 
Table 4. Insulin and proinsulin in pancreatic tissue of normal, somatotrophic diabetic and metasomatotrophic diabetic dogs

\begin{tabular}{llllll}
\hline Dogs & $\begin{array}{l}\text { No. of } \\
\text { dogs }\end{array}$ & $\begin{array}{l}\text { Insulin } \\
(\mathrm{nmol} / \mathrm{g})\end{array}$ & $\begin{array}{l}\text { Proinsulin } \\
(\mathrm{nmol} / \mathrm{g})\end{array}$ & $\begin{array}{l}\text { Proinsulin } \\
(\mathrm{mol} \%)\end{array}$ \\
\hline $\begin{array}{l}\text { Normal } \\
\begin{array}{l}\text { Growth } \\
\text { hormone }\end{array}\end{array}$ & 3 & 16 & \pm 9 & $0.24 \pm 0.14$ & $2 \pm 0.3$ \\
$\begin{array}{l}\text { (6 days) } \\
\text { Metasomato- } \\
\text { trophic } \\
\text { diabetic }\end{array}$ & 6 & $0.82 \pm 0.33$ & $0.11 \pm 0.03$ & $11 \pm 2$ \\
(14 months) & & $0.25 \pm 0.08$ & $0.019 \pm 0.008$ & $10 \pm 1$ \\
\hline
\end{tabular}

Values are expressed as mean \pm SEM

creas extract were reduced to about 1.6 and $8 \%$ of normal and the proportion of proinsulin remained high (Table 4).

\section{Discussion}

Insulin and proinsulin were present in normal fasting dog serum in the molar proportion of $71: 29 \%$, while in the pancreas the proportion of proinsulin was much lower. Comparable relations in man have been attributed to the secretion of IRI similar in composition to that contained in the pancreas and to the higher rate of clearance of insulin than of proinsulin from the systemic and portal circulations $[1,3,30]$.

The rise in serum IRI produced by growth hormone in the $\operatorname{dog}[21,31,32]$ is now shown to be due to elevation in both insulin and proinsulin. The extent and promptitude of these rises (seven- and 18-fold, respectively, after one day of treatment) are indicative of increased rates of secretion. While the influence of growth hormone on the clearance of these peptides from the circulation is not yet known, the absence of change in the systemic clearance of IRI [33] suggests that this factor may not be of primary importance. The increased proportion of proinsulin in serum produced by growth hormone suggests that the rate of secretion of proinsulin by the pancreatic beta cells was increased to a greater extent than that of insulin.

Growth hormone administered for several days to dogs depletes the beta cells of granules [34] and the pancreas of its insulin content [21,31]. The accompanying increase in the proinsulin proportion in the pancreas indicates that in the beta cells the relative proportion of immature granules $[35,36]$ and/or of a cytoplasmic fraction $[8,9,37]$ both of which are rich in proinsulin, may be increased. It has been suggested that the cytoplasmic fraction may be released by a non-granular route, under conditions of high secretion rate $[9,37]$. These pancreatic and serum changes suggest that growth hormone caused in the fasting state a preferential release of immature granules or of a cytoplasmic fraction, to produce an increase in the proportion of proinsulin in the circulation.
In the response of healthy subjects to glucose infusion, the systemic rise in insulin exceeds that in proinsulin: the effect has been attributed to accelerated secretion of IRI, similar in composition to pancreatic IRI, and to the consequent lesser influences of the concurrent differential clearances of these peptides $[1,3,30]$. This decrease in the serum proinsulin proportion in response to glucose infusion was found also in normal dogs. Growth hormone magnified the insulin response to glucose infusion, while the proinsulin proportion decreased. The reśult suggests that growth hormone enhanced the secretory response of the beta cells in the release of mature granules.

Metasomatotrophic diabetes is due to beta cell damage produced by prolonged over-stimulation by growth hormone and resulting in reduced synthesis and secretion of insulin $[20,38]$. At one month of this diabetes, none of the dogs had received insulin treatment, serum insulin was low and the proportion of proinsulin was elevated. In the small amount of insulin remaining in the pancreas after 14 months of this diabetes, the proportion of proinsulin was high, which may be indicative of deficient conversion of proinsulin to insulin and C-peptide. The increased proportion of proinsulin in the circulation may be due to an increase in the proportion of proinsulin in the beta cell secretion. The absence of change in serum insulin and proinsulin after glucose infusion in this diabetes is indicative of inability of the beta cells to respond to this stimulus. In view of the existing hyperglycaemia, this deduction could be questioned; however, IRI release responses to other stimuli were also absent [20]. In normal dog pancreas, the concentration and amount of IRI were in the decreasing order of tail, body and head regions, in agreement with other observations [39]. In growth hormone treatment and in metasomatotrophic diabetes, the reductions in pancreatic IRI were most pronounced in the tail region.

In relation to these observations, only very brief mention can be made of the extensive studies on insulin and proinsulin in diabetes mellitus [1]. In diabetic insulinopenic patients, the increase in the proinsulin component was attributed to the secretion of immature granules containing a high proportion of proinsulin [10]. High proinsulin levels were found in maturity-onset diabetics $[12,14]$ and a high proportion of proinsulin was secreted by insulin-requiring diabetics [13], presumably due to defective formation of mature secretor granules by the beta cells.

In summary, the serum proinsulin proportion is increased by growth hormone treatment, in association with hypersecretion of insulin and hyperinsulinaemia. The proinsulin proportion in serum is also increased in metasomatotrophic diabetes, associated with hyposecretion of insulin and hypoinsulinaemia. 
Acknowledgements. The investigation was supported by the Medical Research Council of Canada, Grant No. 1186, the J. P. Bickell Foundation and the Canadian Diabetes Association. Dr. J. Pierluissi was granted Fellowships by the Universidad Central de Vcnezuela and the Consejo Nacional de Investigaciones Cientificas y Tecnologicas, Venezuela. We are grateful for the donations of growth hormone from Dr. H. D. Bett and of antibody reagents for immunoassay procedures from Dr. Strath Wilson and Dr. A. M. Fisher of the Connaught Medical Research Laboratories, and of insulin, proinsulin and connecting peptide from Dr. R. E. Chance of the Eli Lilly Laboratories. We are grateful to our colleagues Dr. K. S. Rastogi, Dr. B. J. Lin, and Dr. C. C. Yip for their help in this work.

\section{References}

1. Rubenstein AH, Melani F, Steiner DF (1972) Circulating proinsulin: immunology, measurement, and biological activity. In: Steiner DF, Freinkel N (eds) Handbook of physiology, Section 7, Endocrinology, vol 1, Endocrine Pancreas. American Physiological Society, Washington DC pp 515-528

2. Heding LG, Larsen UD, Markussen J, Jørgensen KH, Hallund $O$ (1974) Radioimmunoassays for human, pork and ox C-peptides and related substances. Horm Metab Res (Suppl) 5:40-44

3. Horwitz DL, Starr JJ, Mako ME, Blackard WG, Rubenstein AH (1975) Proinsulin, insulin, and C-peptide concentrations in human portal and peripheral blood. J Clin Invest 55: $1278-1283$

4. Melani F, Rubenstein AH, Steiner DF (1970) Human serum proinsulin. J Clin Invest 49: 497-507

5. Gorden P, Sherman B, Roth J (1971) Proinsulin-like component of circulating insulin in the basal state and in patients and hamsters with islet cell tumors. J Clin Invest 50:2113-2122

6. Gutman RA, Lazarus NR, Penhos JC, Fajans S, Recant L (1971) Circulating proinsulin-like material in functioning insulinomas. N Engl J Med 284: 1003-1008

7. Sherman BM, Pek S, Fajans SS, Floyd JC Jr, Conn JW (1972) Plasma proinsulin in patients with functioning pancreatic islet cell tumors. J Clin Endocrinol Metab 35:271-280

8. Creutzfeldt W, Creutzfeldt C, Frerichs H, Track NS, Arnold R (1976) Histochemistry, ultrastructure and hormone content of human insulinomas. Horm Metab Res (Suppl) 6:7-18

9. Track NS, Frerichs H, Creutzfeldt W (1974) Release of newly synthesized proinsulin and insulin from granulated and degramulated isolated rat pancreatic islets. The effect of high glucose concentration. Horm Metab Res (Suppl) 5:97-103

10. Gorden P, Hendricks CM, Roth J (1974) Circulating proinsulin-like component in man: increased proportion in hypoinsulinemic patients. Diabetologia 10:469-474

11. Burgham GA, Etteldorf JW, Trouy RL, Kitabchi AE, Keslensky $S$ (1976) Insulin and proinsulin in normal and chemical diabetic children. J Pediatr 89:48-53

12. Mako ME, Starr JI, Rubenstein AH (1977) Circulating proinsulin in patients with maturity onset diabetes. Am J Med 63: $865-869$

13. Heding LG (1977) Specific and direct radioimmunoassay for human proinsulin in serum. Diabetologia 13: 467-474

14. Rainbow SJ, Woodhead IS, Yue DK, Luzio SD, Hales CN (1979) Measurement of human proinsulin by an indirect twosite immunoradiometric assay. Diabetologia 17:229-234

15. Luft R, Cerasi E, Werner S (1969) The effect of moderate and high doses of human growth hormone on the insulin response to glucose infusion in prediabetic subjects. Horm Metab Res 1: 111-115

16. Pek S, Fajans SS, Floyd JC Jr, Knopf RF (1974) Clinical conditions associated with elevated plasma levels of glucagon. In: Malaisse WJ, Priart J, Vallance-Owen J (eds) Excerpta Medica, Int Congr Ser 312: 207-213

17. Whittaker PG, Taylor KW (1980) Direct effects of growth hormone on rat islets of Langerhans in tissue culture. Diabetologia $18: 323-328$
18. Sirek A, Vranic M, Sirek OV, Vigas M, Policova Z(1979) Effect of growth hormone on acute glucagon and insulin release. Am J Physiol 237: E107-E112

19. Pierluissi J, Pierluissi R, Ashcroft SJH (1980) Effects of growth hormone on insulin release in the rat. Diabetologia 19:391-396

20. Pierluissi J, Campbell I (1980) Metasomatotrophic diabetes and its induction: basal insulin secretion and insulin release responses to glucose, glucagon, arginine and meals. Diabetologia 18: 223-228

21. Campbell J, Pierluissi J. Green GR (1978) Somatotrophic diabetes: insulin release responses to arginine and glucagon in dogs. Diabetologia 15: $205:-212$

22. Davoreen PR (1962) The isolation of insulin from a single cat pancreas. Biochim Biophys Acta 63: 150-153

23. Campbell J, Rastogi KS (1968) Elevation in serum insulin, albumin, and FFA, with gains in liver lipid and protein, induced by glucocorticoid treatment in dogs. Can J Physiol Pharmacol 46: $421-429$

24. Hunter WM, Greenwood FC (1962) Preparation of iodine-131 labelled human growth hormone of high specific activity. Nature 194: 495-496

25. Davis BJ (1964) Dise electrophoresis. II. Method and application to human serum proteins. Ann NY Acad Sci 121: 404-427

26. Hales CN, Randle PJ (1963) Immunoassay of insulin with insulin-antibody precipitate. Biochem J 88: 137-146

27. Chance RE, Ellis RM, Bromer WW (1968) Porcine proinsulin: characterization and amino acid sequence. Science 161: $165-167$

28. Yanaihara N, Yanaihara C, Sakagami M, Sakura N, Hashimoto T, Nishida T (1978) Synthesis of C-peptides and human proinsulin. Diabetes 27: 149 160

29. Okuda J. Okuda G (1969) A rapid polarographic microdetermination of glucose with glucose oxidase. Clin Chim Acta 21: 365-367

30. Starr JI, Rubenstein AH (1974) Metabolism of endogenous proinsulin and insulin in man. $\mathrm{J}$ Clin Endocrinol Metab 38: 305-308

31. Campbell J, Rastogi KS (1966) Growth hormone-induced diabetes and high levels of serum insulin in dogs. Diabetes 15 : $30-43$

32. Pierluissi J (1979) Insulin and glucagon levels in young dogs treated with growth hormone. In: Pierlussi J (ed) Endocrine Pancreas and Diabetes. Excerpta Medica, Int Congr Ser 459: 220:-229

33. Campbell J, Rastogi KS (1969) Actions of growth hormone: Enhancement of insulin utilization with inhibition of insulin effect on blood glucose in dogs. Metabolism 18:930-944

34. Volk BW, Lazarus SS (1962) Ultramicroscopy of dog islets in growth hormone diabetes. Diabetes 11:426-435

35. Lacy PE (1975) Endocrine secretory mechanisms. Am J Pathol 79: 170-187

36. Sorenson RL, Steffes MW, Lindall AW (1970) Subcellular localization of proinsulin to insulin conversion in isolated rat islets. Endocrinology 86: 88-96

37. Track NS, Creutzfeldt C, Creutzfeldt W (1976) Human insulinoma tissue: in vitro studies of proinsulin/insulin biosynthesis and release. Horm Metab Res (Suppl) 6:19-25

38. Pierlussi J, Norwich KH, Green GR, Campbell J (1978) Insulin kinetics in metasomatotrophic diabetes. Metabolism 27:61-70

39. Gersell DJ, Gingerich RI, Greider MH (1979) Regional distribution and concentration of pancreatic polypeptide in the human and canine pancreas. Diabetes $28: 11-15$

Received: 16 June 1980

and in revised form: 10 June 1981

Dr. J. Campbell

Department of Physiology

Medical Sciences Building

University of Toronto

Toronto, Ontario

Canada, M5S 1 A8 